ARTICLE

\title{
A close examination of the role and needed expertise of brokers in bridging and building science policy boundaries in environmental decision making
}

Ronlyn Duncan (10) ${ }^{1}$, Melissa Robson-Williams (i) ${ }^{1 凶} \&$ Sarah Edwards (i) ${ }^{2}$

\begin{abstract}
Knowledge brokers are often portrayed as neutral intermediaries that act as a necessary conduit between the spheres of science and policy. Conceived largely as a task in packaging, brokers are expected to link knowledge producers and users and objectively translate science into policy-useable knowledge. The research presented in this paper shows how brokering can be far more active and precarious. We present findings from semistructured interviews with practitioners working with community-based groups involved in collaborative water planning in New Zealand's South Island region of Canterbury. Working in a highly conflicted situation, our brokers had to navigate different knowledges and epistemic practices, highly divergent values and grapple with uncertainties to deliver recommendations for regional authorities to set water quality and quantity limits. Conceiving science and policy as interlinked, mutually constitutive and co-produced at multiple levels, rather than as separate domains, shows how the brokers of this study were not only bridging or blurring science policy boundaries to integrate and translate knowledges. They were also building boundaries between science and policy to foster credibility and legitimacy for themselves as scientists and the knowledge they were brokering. This research identifies further underexplored aspects of brokering expertise, namely, the multiple dimensions of brokering, transdisciplinary skills and expertise, 'absorptive' uncertainty management and knowledge translation practices.
\end{abstract}

${ }^{1}$ Manaaki Whenua Landcare Research, Lincoln, New Zealand. ${ }^{2}$ Lincoln University, Lincoln, New Zealand. ${ }^{凶}$ email: robson-williamsm@landcareresearch.co.nz 


\section{Introduction}

growing body of research on knowledge brokers has emerged over recent years in response to on-going calls to close the 'know-do gap' (Bennett and Jessani, 2011, p. 3) and foster sustainability science utilisation (or remedy the lack thereof) (Cash et al., 2003; Cash et al., 2006; Leith et al., 2017; Van Kerkoff and Pilbeam, 2017). Popularised accounts of brokers, influential in New Zealand, portray them as neutral intermediaries involved in packaging knowledge and blurring or bridging what are often characterised as formidable boundaries between the spheres of science and policy to improve communication and translation and deliver useable knowledge for policy (Bennett and Jessani, 2011; Gluckman, 2014, p. 165; Gluckman, 2017a, 2017b, 2017c; Pielke, 2007; WHO, 2004). Notwithstanding these popular accounts of what brokers are expected to do, it is now well known that brokering, knowledge translation and building credibility, legitimacy and salience for science and policy requires more than better packaging to make knowledge useable (see Cash et al., 2003; Cash et al., 2006; Funtowicz and Ravetz, 1991; Guston, 2001; Leith et al., 2017; Leith et al., 2014; Leith and Vanclay, 2015; Lavis et al., 2006; Meyer, 2010; Meyer and Kearnes, 2013; Pettit et al., 2011; Turnhout et al., 2013; Sarewitz and Pielke, 2007; Tuinstra et al., 2006).

To contribute to an understanding of how brokers navigate situations involving different knowledges and epistemic practices and highly divergent values, we have examined brokering in collaborative water planning in New Zealand's South Island region of Canterbury. Here, groups of scientists, planners, indigenous people and community representatives have been involved in collective decision-making to make recommendations for regional authorities to set water quality and quantity resource limits. The brokers in this study were traversing multiple boundaries to produce policy-usable and practically-intelligible knowledge in a value-laden context that had to be credible and legitimate for different audiences and across multiple domains.

This paper is organised around salient themes in the knowledge broker literature, which we review in the next section: interpretation of the broker role, doing boundary work, and translation. After providing contextual information and describing the methods used in this study, we then structure our results and discussion according to these same themes. It will be shown that the popularised accounts of the broker betray what goes on in practice. In reflecting on how brokers grappled with the evident tensions between the ideal broker and the realities of the messiness and value-laden interconnectedness of science and policy, this research provides important insights for building brokering expertise.

\section{Knowledge brokering in theory}

Interpretation of the broker role. Pielke (2007) identifies several roles scientists can play in contributing to public policy: pure scientist, science arbiter, issue advocate and honest broker, with a fifth being the stealth issue advocate. According to Pielke (2007), scientists operating as brokers that are 'honest' can pave the way for the safe movement of scientific knowledge into policy with their credibility intact and policy justifiably evidence-informed (see also Gluckman, 2014, 2017a, 2017b and 2017c). The honest broker is cast as playing a role that fosters credibility for scientists and legitimacy for science through opening-up or clarifying options for policy-makers, in contrast to narrowing them down (i.e., the science arbiter), not providing useful options at all (i.e., the pure scientist), advocating a particular position (i.e., the issue advocate) or wrapping one's values in science (i.e., the stealth issue advocate). Brokers are expected to distance themselves from the value-laden political fray and operate as translators rather than adjudicators of decisions or advocates for preferred options (see also Weinberg, 1972 for similarities with the concept of trans-science).

Pielke's honest broker has become popular in policy and science circles in New Zealand through the work of Sir Peter Gluckman, the inaugural Prime Minister's chief science adviser. Gluckman (2014, p. 165) cites Pielke's work to argue in Nature (2014) that a 'knowledge broker' rather than an advocate has a better chance of building trust with policy-makers and politicians in providing science advice. In New Zealand, Gluckman has promoted the knowledge broker as someone who helpfully translates but does not advocate, and plays a central role in a 'science advisory ecosystem' populated by science (not policy) institutions and actors. This particular type of brokerage role is expected to 'enhanc[e] the uptake of scientifically developed knowledge into public policy' (Gluckman, 2017c, p. 11).

The science advisory ecosystem that Gluckman's knowledge broker is envisaged to inhabit is what Wehrens (2014, p. 545) identifies as a 'two communities-logic'-where the spheres of science and policy are assumed to be discrete and separate. Wehrens (2014) citing Tuinstra et al. (2006) explains how this logic constructs not only pre-conceived ideas about fixed and preexisting boundaries between science and policy but also a gap between them which invokes gap-filling responses (e.g., better or more targeted or more flamboyant communication). (Wehrens, 2014; see also Leith et al., 2014, 2015, 2017; Lövbrand, 2007; McNie, 2007; Wyborn, 2015) argues that depictions of science and policy, often diagrammatically represented as two separated circles with a third brokerage role intervening in the middle (e.g., for examples see Lavis et al., 2006 p. 622 and Gluckman, 2017c, p. $11)$, are part of the problem.

Wehrens (2014, p. 546) highlights how science and policy are co-produced with boundaries emerging through discourse, practices, and material relations (see also Latour, 2004; Law, 1994; Jasanoff, 2004; Irwin and Wynne, 2003). He states, 'the difference between what counts as a 'scientific' issue and what counts as a 'policy affair' is not something that is given in advance, but rather actively negotiated in practice' (Wehrens, 2014, p. 545). Hence, boundaries that demarcate science and policy are seen as negotiated and emergent (Hoppe et al., 2013; Jasanoff, 2004; Leith et al., 2017). This co-produced conception of science and policy shifts the focus of analysis from finding ways to fill or bridge gaps to thinking about the boundaries themselves, e.g., their stability and flexibility, the discourses and practices that shape and are shaped by boundaries, what science and scientists are embraced and excluded, and other political purposes boundaries can and do serve (Jasanoff, 1987, 1990, 2004).

(Van Kerkhoff and Pilbeam 2017; see also Wyborn et al., 2019) conceive co-production negotiations occurring at multiple levels. This can be at the overarching level of political institutions that shape social and cultural norms over the long-term, what they term civic epistemologies (following Jasanoff, 2004). Within this are the 'knowledge systems' (following Cash et al., 2003) comprising science and policy institutions and organisations that establish processes to address particular issues. It is their third level of 'intervention' that corresponds to the operational level of the broker. Although this research is mainly focused on brokers at the operational or intervention level, it provides insight into how the other levels, especially the knowledge system, shape what brokers do and how they navigate the highly political terrain they have limited control over and are potentially unaware of (Wyborn et al., 2019).

On this basis, boundaries are artefacts to be scrutinised rather than entities to be assumed or taken for granted (Jasanoff, 2004; Latour, 1993; van Kerkhoff and Pilbeam, 2017; Wyborn et al., 2019). 
This fluid image of the dynamics of the science policy interface is different from an image in which a 'gap' between science and policy exists that has to be bridged, or a manifest boundary between science and policy that has to be crossed. The negotiation and establishment of the boundary itself and the definition of science and policy is part of the science policy communication process. It is through boundary work that boundaries are made 'real' (Tuinstra et al., 2006, p. 352).

It is from this perspective that Wehrens (2014, p. 545) argues it is important to understand 'how-and at what moments-these boundaries are maintained, redrawn or re-established-and for what purpose'. Wehrens is referring to boundary work to which we now turn.

Doing boundary work. Tracing the history and cultural dimensions of science, Gieryn (1983) examines the narratives and vocabularies used by scientists to differentiate science from nonscience and, in some cases, to discredit the work of scientists committed to rival theories (Gilbert and Mulkay, 1984). This demarcating talk of scientists has been described by Gieryn (1983, p. 781) as 'boundary work', which seeks to engender 'authority through credibility' (Leith et al., 2017, p. 81). This mode of boundary work is a discursive activity of demarcation. More recently, boundary work has been conceived as useful not only for demarcation (i.e., negotiating authority and credibility) but also co-ordination (i.e., negotiating roles and responsibilities) (Hoppe et al., 2013; see also Jasanoff, 1987; Leith et al., 2017). (Leith et al., 2017; see also Leith et al., 2014) encourage active boundary work, which they see as an essential broker role in approaching sustainability issues that involve negotiating boundaries, values and knowledges and the use of 'boundary objects' (e.g., artefacts such as maps, models and frameworks) that are meaningful for multiple audiences (Star and Griesemer, 1989, p. 387; see also Becker, 2017; Leith and Vanclay, 2015; Meyer, 2010; Wyborn, 2015).

On this basis, boundary work can be seen as a productive way of negotiating the credibility, relevance and legitimacy of science and other knowledges to facilitate the co-production of sustainability outcomes (Cash et al., 2003; Cash et al., 2006; Leith et al., 2017). (Cash et al., 2003, p. 8086; see also Cash et al., 2006) state: '[S]cientific information is likely to be effective in influencing the evolution of social responses to public issues to the extent that the information is perceived by relevant stakeholders to be not only credible, but also salient and legitimate'. Salience is about relevance and is important to end-users. Does the knowledge answer the right questions and is it in a form and provided at a time that is useful? Credibility is about the adequacy of technical evidence and arguments. Were defensible methods, concepts and models used and properly employed? Legitimacy is about fairness and adequacy of the knowledge production process. Were appropriate people and sources of knowledge involved? In a context where multiple knowledges, epistemic practices and divergent values need to be integrated, criteria for determining the credibility and legitimacy of knowledge held by one set of actors is likely to be quite different to others. Fostering these knowledge attributes opens important questions about how boundary work is done in practice. For example, what is the role of the broker in taking responsibility for uncertainties; who decides how these are communicated and how they are navigated between knowledge producers and users; who decides what is an acceptable environmental state and level of uncertainty; how are different knowledges and values aligned, represented and presented in the science work; how is expertise assessed; and how are different knowledge attributes criteria negotiated between and within groups? These are questions our brokers had to grapple with.

Translation. Knowledge translation has been identified as a key role of the knowledge broker (Bennett and Jessani, 2011; Gluckman, 2017a, 2017b, 2017c; Leith et al., 2017; Meyer, 2010; WHO, 2004). As discussed, the translation task is often characterised as the transfer of knowledge from one place to another, where the broker acts primarily as a conduit that enables movement. Bennett and Jessani $(2011$, p. 1) describe it in these terms:

Knowledge is like fine wine. The researcher brews it, the scientific paper bottles it, the peer review tastes it, the journal sticks a label on it, and archive systems store it carefully in a cellar. Splendid! Just one small problem: wine is only useful when somebody drinks it. Wine in a bottle does not quench thirst. Knowledge $[t]$ ranslation ... opens the bottle, pours the wine into a glass, and serves it.

With this analogy, both the broker who serves the wine and knowledge are conceived as separate and unchanged during translation, and the (notably absent) recipient of knowledge plays no part in this process. In contrast, Law (2002, p. 99) maintains, to translate is 'to connect, to displace, to move, to shift from one place, one modality, one form, to another while retaining something. Only something. Not everything. While therefore losing something. Betraying whatever is not carried over'. Machen (2018, p. 6) also identifies translation as an active and displacing process and highlights 'the irreconcilable tension between equivalence and difference'. In other words, in addition to the broader political and institutional landscape that influences what research is done, in conflicting situations such as water resource planning, translation cannot be value-free and brokers cannot be effective if they operate as detached actors.

\section{The context of brokering in collaborative decision-making in Canterbury}

Water is a highly contentious issue in New Zealand especially given its economic importance for agriculture, the increasing concerns about the cultural impact of diminished water quality from agricultural production, as well as the socio-economic impact on New Zealand's clean green image and its tourism sector. To address these issues, in 2011 New Zealand's central government introduced its National Policy Statement for Freshwater Management (NPSFM), which requires regional councils to set limits for water quantity and quality on all waterbodies (MfE, 2017). Prior to the introduction of the NPSFM in 2011, the Canterbury Regional Council (known as Environment Canterbury or ECan) had already moved to set limits under a collaboratively developed Canterbury Water Management Strategy (CWMS). The CWMS vision is to 'enable present and future generations to gain the greatest social, economic, recreational and cultural benefits from our water resources within an environmentally sustainable framework' (CMF, 2009, p. 6). The vision is to be achieved through setting long-term targets for: ecosystem health/biodiversity, natural character of braided rivers, kaitiakitanga (i.e., Māori stewardship), drinking water, recreational and amenity opportunities, water-use efficiency, irrigated land area, energy security and efficiency, regional and national economies, and environmental limits (CMF, 2009, p. 8). The targets are to be 'advanced in parallel' (CMF, 2009, p. 9).

Collaborative committees working to implement the CWMS have become part of Canterbury's regional planning process, which begins with the establishment of a Zone Committee (ZC) for each of Canterbury's ten sub-regions (i.e., zones). A ZC consists of a representative from the regional council and the 
relevant territorial authority, local rūnanga (Māori tribal representatives) and 4-6 representatives from the community. The ZC, in consultation with interest groups, the broader community, and industry, develop a Zone Implementation Programme outlining their aspirations (called priority outcomes), and an addendum, describing a package of actions (statutory and non-statutory) and proposed limits that are expected to deliver the CWMS targets into the future. This collaboratively-derived package is handed over to ECan's planners to guide the writing of a statutory plan that they take through a public hearings process, which eventually culminates in provisions of Canterbury's Regional Plan and recommendations on non-statutory actions.

ZCs were established in the midst of institutional upheaval in Canterbury when in 2010 central government dismissed ECan's elected councillors under the Environment Canterbury (Temporary Commissioners and Improved Water Management) Act, 2010 (the ECan Act) (see Rennie, 2010). This move allowed central government to appoint its chosen commissioners to run the regional council and suspend regional council elections. The Act gave central government and its commissioners a mandate to implement the CWMS without the onus of merit appeals to New Zealand's Environment Court that had been cast as holding up regional planning in the past (New Zealand Government, 2010; LAWF, 2012). In the Environment Court, science had become highly politicised and uncertainty exploited in decisions that often favoured irrigators, thus exacerbating the cumulative effects problem (LAWF, 2012; Weber et al., 2011). This meant that grappling with the politics and addressing scientific uncertainties fell to ZCs and our brokers. In the midst of this upheaval, and the institutional shift that limited merit appeals to the Environment Court, an opportunity arose to change the way science was used in policy. ECan created leadership roles that brought together interdisciplinary technical teams to support planning processes (see Robson, 2014; Robson-Williams et al., 2018). It is the leaders of these technical teams and the brokering activities they engaged in that are the focus of this study.

\section{Methods}

In 2018, semi-structured interviews were conducted with five technical team leaders whose roles were conceived by ECan as brokers. The technical team leaders interviewed covered six of the eight zones in Canterbury that had been through the limit-setting phase of the planning process.

The interviews, which lasted between 90 and $120 \mathrm{~min}$, were digitally recorded and transcribed. Participants were asked to describe their role and its various dimensions, what expertise and personal characteristics they brought to the role, what expectations they were working with for the role, their understanding of the terms broker, co-production, translation and integration, how they fostered credibility and legitimacy with their various audiences, what brokering strategies they adopted and how well they worked (or not), and the challenges they faced.

A thematic analysis of the interview transcripts was undertaken using an inductive and deductive approach (Cope, 2015; Merriam and Tisdell, 2015). Descriptive codes, which were organised using NVivo software as nodes, were derived inductively through reading and re-reading the typed interview transcripts and looking for what appeared important and significant in terms of undertaking the broker role, what characteristics, actions and perspectives were important and how these interacted with the context within which the broker role was created, supported and undertaken. Coding the data was also guided by the research questions, which were informed by the academic literature on knowledge co-production and brokering. The analytical themes that structure the paper, namely, interpreting the broker role, boundary work and translation were derived deductively using theory to identify patterns and interpret meaning to reveal what the brokers saw themselves doing, what they were encountering in doing it, the challenges they faced, their interactions with multiple audiences, the strategies they used to navigate their role and the consequences of their brokering practices (Strauss and Corbin, 1990 cited by Cope, 2015). The research process and interview questions were approved by the Manaaki WhenuaLandcare Research social ethics process (1718/21) and informed consent was obtained from all participants prior to involvement in the study.

It is important to note that one of our authors worked as a broker in two CWMS zones. With co-author RD leading the interviews from questions she developed from her theoretical knowledge, co-author MR-W was interviewed and she helped recruit other participants. Co-author MR-W was present at two of these interviews as part of the research team. While we acknowledge that co-author MR-W's position in the research space influenced what was said, her position as an 'insider' in the brokering field provided an opportunity for reflexivity on both sides of the researcher/researched divide (Law, 2004).

\section{Knowledge brokering in practice}

Interpretation of the broker role. The participants of our study were seeking to emulate Gluckman's (2014) idealised notion of the 'knowledge broker' outlined in section 'Interpretation of the broker role' above. Yet, when asked to give their interpretation of what their role was, it was evident that the situation in which our brokers were working was conflictual, messy and value-laden, and the expertise required went well beyond the ability to simply communicate science. Informant 1 described the role as 'an integrator and a translator' and explained that the broker term was being used deliberately to recast the role of not only scientists but also the regional council in disputes over resource use:

we talked about going from an arbiter of knowledge to a broker of knowledge, so we were trying to really deliberately shift the sense that ECan had the answers and it was the one that decided what was good enough and adequate enough, to saying very explicitly, 'ECan doesn't have all of the answers and we're wanting to try to line things up'. I think it [the broker] was a word that was very deliberately used to signal a change in the role but also to signal a change in attitude (Informant 1).

Informant 2 described the technical lead role as 'somebody who acts as a piece of glue or an integrator'. Informant 4 explained the role as having a number of aspects, namely, science interface with internal and external people, project management and communication to a number of audiences. Informant 5 explained the role was to 'basically co-ordinate a technical team and communicate the science information to the zone committee and the public'. The broker identity did not resonate with informant 3 who questioned the honesty and detachment the broker role implied in the midst of a policy-directed process, where values influenced decisions 'made in the background' all the time. Informant 3 saw the technical lead role as having a significant leadership component', 'the person that holds it all together' and 'had to know the big picture', which included digesting the information and presenting it in a way that was useful for communities.

\section{Doing boundary work}

Supporting not leading. In line with the idealised broker identity, participants talked about brokering involving a deliberate 
commitment not to push a particular solution or allow their personal values to influence the decisions of the ZC:

[our role is] someone who will provide information but without it being pushed in a certain direction. We try to make that as clear as we can at the start, that my role is to advise them [the ZC] on implications of their decisions or give information to help them make their decision but it's the zone committee's decision to make. It's not up to me to tell them how they should make it but if they're making the decision, it's my job to tell them what that decision will mean for them. That's how we've interpreted the term broker (Informant 5).

Acting or being perceived to be acting as an advocate (i.e., pushing a certain outcome) was seen by informant 5 as a threat to one's career:

it would be quite easy to do that [push a certain outcome] but I think we just have to be really careful ... because it's such an important role in such a small industry, that it's quite obvious when someone is going down a certain path and it's not worth risking your reputation. ... If I kind of went down a path of pushing something on the zone committee it could be pretty bad in terms of where I went to next, to try and argue that I was an impartial and independent scientist. I have to keep it in mind the whole time but it is a balance to try and give them information and make sure they understand what they're doing, without telling them what they should do (Informant 5).

Informant 2 explained why it was important for technical leads to support not lead and the importance of having the community make the decisions:

[in the past] we were using the words options and choices and it was quite one dimensional. ... This was before terminology around the broker but the same principle. ... it's not a scientist's role to just provide the number at this point on the curve, as being the magic number but when we really know that actually it's a choice along here [the curve]; if we want to be precautionary, we choose it here and if we want to be resource use enabling, we choose it here. The scientist has absolutely no idea about what the implications of those choices are for all sorts of other things, so how could they possibly make that choice on their own.

Transparency and stripping out value statements. Those that identified with the broker identity saw the role as allowing them to engage in the policy sphere while retaining their credibility as scientists. They made deliberate efforts, for example, to ensure assumptions embodied in the modelling were transparent and that the science did not convey value judgements that risked diminishing credibility (i.e., by appearing to sway decisions in a particular direction):

We tried very hard and that's something I'm very conscious of, that any value judgement was stripped out of the language that we used when we talked about the outcomes. That's why the likelihood/unlikelihood of the values [being met] was an important step, in order so people, if they wanted more agriculture or wanted less agriculture, people wanted more of this or less of this, that they were seen to be dealt with in an entirely even-handed manner. That was quite an important, purposeful thing in trying to build trust (Informant 1).

Reading people. Discerning what was credible and salient for the $\mathrm{ZC}$ required more intuitive communication skills: [there's] the technical side of it but I think there's very much a people side of it, which is harder to describe and put your finger on, which is not mechanical and hand cranking, it's people reading (Informant 2).

Reading people was a key aspect of communication, which helped build trust with the ZC members and the broader public who attended meetings and was described as requiring the right doses of humility that encouraged people to give the broker a chance and listen rather than folding their arms. It involved interpreting body language and taking account of where people were at on what was described as each person's trajectory of knowledge and realising that different people are always at different points along that journey. Informant 2 noted that while people might start the process with folded arms, by the end they were usually working with you and there was mutual respect.

Informant 2 maintained what was key to this transformation was being, and being seen as, someone seeking to find a solution for multiple parties. This involved listening in the formative stages of the ZC process to hear everyone's aspirations and ensure they were all on the table (e.g., via a modelled scenario), no matter how unrealistic or unpalatable it might be to others around the table. Extending responsibility for choosing modelling scenarios distributed authority and responsibility between science and policy actors, which fostered credibility for the broker and legitimacy for the process.

Reading people also required listening carefully to what people were saying. So too was being honest and sincere in interactions, committing to following up with answers to people's questions, having a willingness to change approach if new information came to light, the ability to boil very complex ideas down to concepts that could connect with people or link to things people understood, being respectful of people's abilities and 'not treating them like idiots' (Informant 3), acknowledging history, being fair and taking on board the views of others, not jumping to conclusions, presenting science as one way of seeing things and asking what people thought of that to draw them in and engage them in understanding the big picture, and not privileging some knowledges over others.

Engaging with multiple audiences. Our brokers were communicating with a range of actors, including scientists within their discipline, scientists from other disciplines, as well as planners and decision-makers within ECan. There were also groups and teams within the collaborative processes (e.g., zone committees, stakeholder groups) alongside the public, interest groups, and ultimately, public hearings commissioners. While our brokers found the Cash et al. (2003) salience, credibility and legitimacy framework useful, they discovered there was a range of differing expectations and judgements about what was credible, salient and legitimate:

I very deliberately used Cash's framing here-what is legitimate, credible and salient for those different people? Therefore, what was fit for purpose for them, and very rapidly, we got to splitting the credibility into local and global credibility. Global credibility, the language used, that's the kind of peer review stuff, making sure that it's robust methodology, but local credibility is much more relational, much more, 'does this make sense to me on the ground and in terms of my own experience'? You might have lots of scientists, you might have lots of degrees, you might have lots of great models but it doesn't resonate with me. that's the distinction we ended up making (Informant 1).
Taking time. Time was identified as an important factor in fostering salience, credibility and legitimacy-time spent talking, 
time taken to answer questions, time spent going and looking at issues of concern to people, length of time involved in the process and time given to conduct the process. This was a key issue as time was in short supply. Deadlines imposed by Commissioners working under the ECan Act created enormous pressures on staff and ZC members (see Henley, 2014; Fenemor, 2014).

If you've got 10 years, then sweet, you could do everything. If you are challenging water quality, quantity and both surface water and ground water, you want to tap into local biodiversity, no way (Interview 4).

In several cases, $\mathrm{ZC}$ members were unable to make decisions within the given timeframes and deadlines had to be extended. Allowing extensions gained credibility for technical work and legitimacy for the process. However, in one zone, several shorter extensions were given. This did not give the same opportunity to improve the fundamentals of the technical work as a single longer extension would have done. This shows the challenges for brokers managing science to meet policy demands.

Translation. A significant part of the brokers' job was translation, which was identified as having several dimensions and challenging for a range of reasons.

Describing consequences in meaningful ways. In each sub-regional zone, to help ZC members make choices about recommended actions and incorporate uncertainty into their decision-making, an assessment framework was created to test possible future scenarios. In these assessment frameworks, indicators were modelled to understand the implications of each scenario for achieving the ZC's aspirations. Some brokers presented the results by way of a matrix (Fig. 1).

This matrix synthesised the modelling results to help the ZC assess the consequences of different scenarios across the range of priority outcomes. Informant 1 explained the thinking behind the assessment framework:

[the ZC has] said that this is what [they're] interested in and this is what it looks like, so the modelling is saying that [any particular scenario] is more or less likely to deliver on those things. We were deliberately trying to inhabit their value judgements and use our information, so basically trying to minimise the number of times that we had to make a value judgement within the technical team about whether something was acceptable, unacceptable, good or bad.

Although the matrix worked well for some brokers, for others, new ways of synthesising information to make it meaningful were necessary.

I really like the traffic light system [i.e., Fig. 1] because inbuilt in that is some degree of uncertainty because it's all relative and it's magnitude and direction of change type stuff. To me, it's really intuitive but I feel, for this zone committee and this community, it just went down like a cold bag of sick. Whether that was the way that I explained it or maybe they needed more context, I'm not sure or maybe it just didn't work for them (Informant 4).

What was eventually identified as needed [for this particular region] was a more geographic approach to delivering the science so potential decisions connected more with places people knew:

They were like, 'Where is this?' It was a consensus. It was the first time the zone committee had true consensus around the table, 'We want geographic', which was great because I could go back to the tech team and say, 'Listen fellas, this is what we're doing now. We are doing geographic'. The other thing they said was, 'We don't want to be lectured to, we want to be front and centre and we want to discuss' (Informant 4).

For this broker, salience (and, consequently, credibility and legitimacy) was lacking until the geographic approach was adopted and roles were renegotiated. In this zone, there were also concerns that ZC members were getting bogged down in the detail of the technical work (Informant 4). It was concluded by this zone's broker that the ZC needed to take a 'helicopter' view of the issues to rise above the detail and the uncertainties to stay sufficiently focused on the big picture.

Integration. Integration was identified as an important aspect of translation and was required to populate the assessment framework. It was described in terms of 'bring [ing] together different knowledge sources and not to privilege one over others, of different qualities, or different types of information' (Informant 1).

Informant 2 highlighted the people and political dimensions of integration:

integrating both in the technical space, the multiple disciplines, but also beyond that into integrating, well what is all that telling us in relation to the policy framework we're currently working under. ... integration with the people and where the community's at and what the participants' values are in the political environment.... Your primary role was integrating, when you're a technical broker, is integrating those multi-disciplines but I guess I'm just making the point that it goes beyond that, into those other realms (Informant 2).

Informant 5 explained it was important for the $\mathrm{ZC}$ to understand that what came out of integration could be difficult to interpret:

We try to integrate different parts or different types of information, different knowledge, whether it's cultural perspectives ... it's only one part of the story and we just have to keep reminding the zone committees that they can't just look at one part of the picture and get a full answer. They'll get an answer but they need to look at multiple different avenues and different sources of values.

While not using the term integration, Informant 3 talked about the necessity of building an overall understanding of the hydrological system, which included bringing in local knowledge to evaluate the implications of historical actions on the current freshwater situation.

Integration was required under the CWMS, New Zealand's Resource Management Act, 1991 and the NPSFM to extend to indigenous knowledge, referred to as Mātauranga Māori. This was a challenging aspect of integration in some processes:

It [Mātauranga Māori] came in this glass box ... but I wasn't really able to provide any tools [for communities] about how you interrogate it ... with some of the other knowledges [like science], you can pick it up and say, 'Well, I'm not sure I believe that, that doesn't really fit with my knowledge' people pushed it and pulled it in a way that I was very prepared for and familiar with and was really happy to encourage. With Mātauranga [Māori], I lacked expertise about how you interrogate [and] whether ... it is appropriate for you to push it and pull it and pick it apart and say, 'I don't really get that bit' (Informant 1).

Translation is 'bloody risky'. An extensive amount of technical work and modelling sits behind an output like the assessment 


\begin{tabular}{|c|c|c|c|c|c|c|c|}
\hline Priority outcomes & Scenario 3 & Scenario $2+$ & Current & Scenario 1 & Scenario 2 & $\begin{array}{l}\text { Solutions } \\
\text { Package } 1\end{array}$ & $\begin{array}{l}\text { Zone } \\
\text { Committee } \\
\text { Solutions } \\
\text { Package }\end{array}$ \\
\hline & \multicolumn{7}{|c|}{ Does the scenario support priority outcomes? } \\
\hline $\begin{array}{lr}\text { Thriving } & \text { communities } \\
\text { and } & \text { sustainable } \\
\text { economies } & \end{array}$ & $\begin{array}{l}\text { Unlikely to } \\
\text { improve } \\
\text { across } \\
\text { whole } \\
\text { catchment }\end{array}$ & $\begin{array}{l}\text { Probably } \\
\text { improved }\end{array}$ & $\begin{array}{l}\text { Possibly } \\
\text { supported } \\
\text { currently }\end{array}$ & As current & $\begin{array}{l}\text { Probably } \\
\text { improved }\end{array}$ & $\begin{array}{l}\text { Probably } \\
\text { improved }\end{array}$ & $\begin{array}{l}\text { Probably } \\
\text { improved }\end{array}$ \\
\hline $\begin{array}{l}\text { High quality and secure } \\
\text { supplies of drinking } \\
\text { water }\end{array}$ & Possibly & Possibly & $\begin{array}{l}\text { Possibly } \\
\text { supported } \\
\text { currently }\end{array}$ & Unlikely & Unlikely & Unlikely & Unlikely \\
\hline $\begin{array}{l}\text { Wahi Tapu and mahinga } \\
\text { kai are respected, } \\
\text { understood, protected } \\
\text { and enhanced }\end{array}$ & Possibly & Possibly & $\begin{array}{l}\text { Unlikely/is } \\
\text { not } \\
\text { supported } \\
\text { currently }\end{array}$ & $\begin{array}{l}\text { Highly } \\
\text { unlikely/no }\end{array}$ & $\begin{array}{l}\text { Highly } \\
\text { unlikely/no }\end{array}$ & Possibly & Possibly \\
\hline $\begin{array}{l}\text { Healthy lowland } \\
\text { streams }\end{array}$ & Possibly & Unlikely & $\begin{array}{l}\text { Unlikely to } \\
\text { be } \\
\text { supported } \\
\text { currently }\end{array}$ & $\begin{array}{l}\text { Highly } \\
\text { unlikely/no }\end{array}$ & $\begin{array}{l}\text { Highly } \\
\text { unlikely/no }\end{array}$ & Probably & Probably \\
\hline $\begin{array}{l}\text { Te Waihora is a healthy } \\
\text { ecosystem }\end{array}$ & Probably & Possibly & $\begin{array}{l}\text { Unlikely to } \\
\text { be } \\
\text { supported } \\
\text { currently }\end{array}$ & Unlikely & Unlikely & Probably & Probably \\
\hline $\begin{array}{l}\text { Hill-fed waterways } \\
\text { support aquatic life and } \\
\text { recreation }\end{array}$ & Possibly & Probably & $\begin{array}{l}\text { Possibly } \\
\text { supported } \\
\text { currently }\end{array}$ & Possibly & Probably & Probably & Probably \\
\hline $\begin{array}{l}\text { Enhanced indigenous } \\
\text { biodiversity across the } \\
\text { Zone }\end{array}$ & Possibly & Possibly & $\begin{array}{l}\text { Unlikely to } \\
\text { be } \\
\text { supported } \\
\text { currently }\end{array}$ & Unlikely & Unlikely & Probably & Probably \\
\hline
\end{tabular}

Fig. 1 Extract from the executive summary of the planning report that explains the technical team's assessment framework for a range of scenarios and their predicted consequences for the ZC priority outcomes (Robson, 2014, p. 24). This figure is not covered by the Creative Commons Attribution 4.0 International License. Reproduced with permission of the author; copyright (c) the author, all rights reserved.

matrix (Fig. 1). It required the brokers to make many decisions on where to delineate categories and to enable the communication of the categories and their predicted implications through the different colour codes that represented progressively better or worse effects on envisaged community outcomes. This involved constantly testing these with others to ensure they were defensible but also grappling with the uncertainties created by the assumptions that fed into the modelling.

This made translation an '80/20 thing' (Informant 1). The broker had to make the call on what information to include and what details to present to support the discussion but not submit to the temptation of overloading the ZC with more and more detail, in an attempt to be more 'honest'. This translation process to make the science useable for community decision-making that involves leaving out technical details and uncertainties, and making value judgements on what is meaningful and necessary, was described as 'high risk' (Informant 2):

You're trying to do something that can be incredibly useful and powerful but also bloody risky and a high level of responsibility in terms of, jeepers, if you translate that in a way that-you've just got to wear that responsibility and deal with it as best you can by being aware of the fact that you're human and have your own value sets and being aware of the role you're trying to play (Informant 2).

Making these $80 / 20$ decisions was not just about what to communicate but reached far back into the technical work. One broker recalled that a 'modelling assumptions log book' was created to document the decisions made to create boundaries around the work programme to enable tight timeframes to be met. The problem our broker faced was that technical team modellers were not comfortable with the timeframes and argued it would take far longer to do what was being asked. As time was in extremely short supply, the log book allowed responsibility for boundary decisions to be documented and taken by the technical lead.

Informant 1 identified the issue of uncertainty as an important aspect of translation, for conveying information and making decisions. It was argued that how uncertainty was handled and the responsibilities for managing and communicating uncertainties differentiated the role of the broker from the scientists in the technical team that provided technical inputs:

The translation role is how do you give enough respect to all of the [technical] work that's been done at this level but make it so people can actually use that information, in order to form a decision. A lot of that is as an individual [broker], how much you're prepared to take the burden of uncertainty on you and say this is $80 \%$ right, so this is enough for you to make the decision. ... For me the translation role was how much are you prepared to synthesise, assimilate and to bring these things together in order to help somebody [i.e., the ZC] make a decision (Informant 1).

It's grey, not black and white. Translation also involved reading the political environment and recognising planning imperatives. Informant 2 made a distinction between brokering technical knowledge and brokering a decision: 
If you're too pure ... and take the 'I'm only interested in providing brokered and objective knowledge for the options', ok, but you run the risk of being less effective and expedient at the expense of purity.

Time and resource constraints alongside planning decisions influenced how translation was done and the direction of the coproduced knowledge. For example, for ECan to be able to enforce rules in a consistent way within the existing compliance framework, it would not be realistic to develop the technical work for five options for the $\mathrm{ZC}$ to assess when two or three are the only ones likely to be adopted by ECan given the technical leads knowledge of the organisation's requirements. Hence, the technical lead had to make a judgement call on not being disinterested in terms of where to direct energy and resources. It was recognised this was a grey area rather than black and white. It meant translation was often more about being realistic in contrast to purity, which was deemed unrealistic, potentially counter-productive and a risk to the broker's credibility with the ZC and the process overall if ZC time was wasted going down pathways that had limited chance of success. However, going too far down this route risked brokers' credibility with other parties.

The imperatives of planning were experienced by brokers in other ways. For example, the need for a number in a plan. Informant 1 stated:

we received quite a lot of pressure, which was, 'Just give me a number,' not quite any number will do but, 'Just give me a number,' with the subtext that that number equals certainty, because it's a fixed quantum.

Informant 1 highlighted the pressures and tensions created by calls for a number given the uncertainties:

they [i.e., planners] were feeling the tensions of time ... if we're going to put it in a plan, we need certainty. So the pressure coming this way and then from the other way [i.e., scientists], it was saying, 'That's not possible because you've got all of these [uncertainties]' and then they would list all of the many ways that it's uncertain and there being this untenable situation ... in the middle.

Our brokers felt stuck in the middle and talked about needing to have a 'thick skin'. For example, given how contentious the issues were, the high economic stakes, and the uncertainties involved, brokering involved dealing with personal attacks, which were described as 'vicious stuff, and navigating many highly charged public meetings, which was mentally and emotionally draining. Informant 3 revealed that undertaking this role was a 'very, very difficult part of my career'. Not taking things personally was identified as challenging but necessary. In reflecting on what advice should be given to other brokers, informant 4 stated:

You need to know that [the technical lead role] is going to be difficult, that it can be really challenging, lots of people are going to disagree, that you're going to be in situations where some people are literally just going to lose their crutch.

\section{Discussion}

At the operational level, our Canterbury brokers conformed with popular accounts of what brokers are expected to do. They were connecting knowledge producers with knowledge users and repackaging knowledge (Bennett and Jessani, 2011; WHO, 2004). In line with Pielke's and Gluckman's ideal type, our brokers were committed to helping ZCs make decisions by supporting and not overtly leading. This involved seeking to operate as a detached actor that was opening-up rather than closing down options. Also, the Cash et al. $(2003 ; 2006)$ salience, credibility and legitimacy framework provided valuable principles for guiding practice (see Robson-Williams et al., 2018). However, to foster the knowledge attributes of Cash et al. $(2003,2006)$ and keep them in balance, brokering practices extended well beyond packaging or bridging a gap between purportedly disconnected spheres of science and policy (Bennett and Jessani, 2011; Gluckman, 2014, 2017a, 2017b, 2017c; WHO, 2004). In Canterbury's conflicted and messy water planning situation, our brokers had to bridge boundaries at the operational level but also build boundaries at the knowledge system level, through negotiating roles and responsibilities to which we now turn.

Interpretation of the broker role: embedded not detached. Although not all participants identified with detachment, giving rise to the 'honesty' implied by Pielke's broker identity, they all became embedded in myriad relations that were essential for building credibility for the knowledge they brokered and legitimacy for the limitsetting processes they were working in. Our brokers had to be intuitive and able to read the needs of their diverse audiences and institutions, which supports the findings of Sarkki et al. (2013) who found that sensitivity was a key broker attribute. They had to respond to what was said, as well as what was unsaid. Communicative strategies had to be developed and honed to build trust and create workable relationships with communities, stakeholders, planners and decision-makers. Brokering capability included confidence, experience, empathy, emotional intelligence and reflexivity. Hence, although there was the semblance of detachment, mainly through processes and protocols, it was impossible for our brokers to operate as detached actors in this contentious water planning context.

Scholars have researched and adapted representations of the role scientists can play in transdisciplinary teams, using terms such as facilitator, intermediary, change agent, self-reflexive scientist, reflective scientist and capacity builder. (e.g., Hilger et al., 2018; Pohl et al., 2010; Sarkki et al., 2013; Wittmayer and Schapke, 2014). For our brokers, their role was not as clear cut. As it turned out, they required expertise in many of these roles. They required the mediating qualities of a facilitator, the ability to integrate across different knowledges as an intermediary, stakeholder networking to build credibility and the creation of working structures and tools like a change agent. The role also required self-reflection, leading to adaptations in the work undertaken or creative boundary defining solutions such as the log book, like the self-reflexive scientists. The role of the reflective scientist (Pohl et al., 2010) is particularly important as accounts do not often capture how brokering requires brokers to be responsible for the credibility and validity of not only their own scientific work but also that of the technical work overall. In this case, our brokers needed to be reflective on behalf of all the science and knowledge produced, the uncertainties, and the integrated and translated outputs, which were essential inputs to other parts of the planning process (Duncan, 2008). This required them to make judgements of adequacy on aspects well beyond their areas of disciplinary expertise. These were unexpected aspects of the role, which raise important questions about how is a broker to know what is good enough when bringing together so many different areas of expertise? In a disciplinary area, tacit knowledge often complements disciplinary training (Schon, 1983). This research shows inter and transdisciplinary expertise is also required and a re-conception of the broker role. Clearly, the broker role is not the sum of the disciplinary parts. In Canterbury, many of these issues were, in part, addressed by the assessment framework to which we now turn.

Doing boundary work: reconceiving the brokering space. In effect, the assessment framework operated as a boundary object (Star and Griesemer, 1989, p. 387; see also Becker, 2017; Wyborn, 
2015) that helped foster salience, credibility and legitimacy for multiple audiences and across multiple domains. It had to be useable for all the groups represented on the $\mathrm{ZC}$, defensible for the planning process and credible for actors outside the process (e.g., interest groups and the broader community). This was a profoundly challenging task for brokers, and very different from operating merely as disinterested conduit between knowledge producers and users.

Accounts from our brokers show how they were betrayed by the 'two communities logic' that portrayed their role as simply linking and communicating to render the technical work salient, credible and legitimate. They found that far more was required. For example, while the assessment framework matrix worked well in some zones it had limited traction in others. Its success faltered when the science was not adequately localised and not appropriately scaled. Many of these issues arose from data gaps and limitations, available technologies and resources, at the operational level, as well as political and organisational imperatives within the knowledge system (Duncan et al., 2016; van Kerkhoff and Pilbeam, 2017; Wyborn et al., 2019).

They also found that notions of what is salient, credible and legitimate (Cash et al., 2003) are not essential qualities but negotiated in practice (Jasanoff, 2004) and emerge from the multiple political, socio-economic and cultural contexts that shape resource planning (i.e., civic epistemologies) and the processes created to bring actors together to address particular issues (i.e., the knowledge system). At the operational level, our brokers found that these knowledge attributes are often at odds with each other given the uncertainties alongside the multiple knowledges, epistemologies and values our brokers were working with (Van Kerkhoff and Pilbeam, 2017; Wyborn et al., 2019). For example, the log book helped the technical lead navigate the brokering space by meeting the needs of multiple sets of actors (i.e., the usual lateral aspects of brokering), as well as linking the big picture with the minutiae (i.e., the vertical dimensions), which collectively can be described as the warp and weft of brokering.

Conceiving science and policy as distinct realms invokes largely lateral responses (i.e., blurring and bridging). This research highlights that there are other spatial dimensions to brokering. The broker needs to be able to do boundary work horizontally and vertically, i.e., horizontal between disciplines, knowledge sources, values and audiences and vertical to orient decisionmakers not only into the depths of the technical work and the uncertainties and unknowns but back out and skyward-so jumping into the helicopter referred to by one of our participants to understand and work with the big picture. These vertical dimensions required our brokers to integrate and translate knowledges, summarise conclusions, make modelling outputs relevant and make decisions on acceptable levels of uncertainty in the technical work to make it meaningful and workable for their multiple audiences. These two dimensions of boundary work were happening at the same time, and often with different expectations. Recognising these multiple dimensions of brokering and the broker space, and the need for practices that can facilitate their navigation, for example, zooming in and zooming out (Fenemor et al., 2011), would appear to be a crucial but underexplored aspect of brokering.

So too is the 'absorptive' role of the broker in managing uncertainties. Management and communication of unknowns is a critical element of research for policy or practice change (Bammer, 2013). This research shows that value-laden collaborative policy-making processes have implications for how uncertainty is managed. While the $\mathrm{ZC}$ was not shielded from the existence of uncertainty (indeed, they grappled with it continuously), neither were they exposed to all of the technical detail.
Some of it was, by necessity, hidden (Duncan, 2008, 2013a). The brokers had to make decisions about managing and communicating uncertainty to not only help the ZC make decisions (i.e., by not passing on all of the technical details of uncertainties) but also to give technical team members permission to limit the scope of their work to enable them to produce contributions to the planning process that were credible (for the scientist) and within the required planning deadlines. In what was described by one broker as an ' $80 / 20$ thing', our brokers took on responsibility for the myriad uncertainties of the technical work that would otherwise have been passed direct to the $\mathrm{ZC}$ or left to inhibit the development of the technical work and the planning process. Conceived by our participants as sharing the burden of uncertainty, brokering involved co-ordination of the science and processes to help scientists hand over their science while being confident they had sufficiently qualified their conclusions to the broker. Taking on the responsibility of what to include and what to leave out of the technical work outputs, as well as in the communication of it meant that our brokers were absorbing responsibility for uncertainty, not just for the $\mathrm{ZC}$ and policymakers, but the technical team as well.

In recognising how intermeshed science and policy are (and need to be to facilitate decisions) at the knowledge system level, our brokers could be more aptly conceived as actively pushing the realms of science and policy apart rather than pulling them together. This meant that in delegating authority, coordinating roles and responsibilities (Hoppe et al., 2013; Leith et al., 2014, 2015, 2017) and managing uncertainties (Duncan, 2008, 2013a), our brokers were using the assessment framework to build rather than bridge or blur boundaries (Evans and Scarbrough, 2014). In contrast, at the operational level, for knowledge to be credible and legitimate with members of ZCs, as well as planners and the statutory process within which all were working, bridging boundaries was a critical part of the work. From the outside looking in, this is a paradox, whereby our brokers are seen to be actively weaving together different knowledges, information and values in their everyday work while simultaneously building boundaries between science and policy at the knowledge system level of co-production to foster credibility, legitimacy and salience within and beyond the ZC.

Translation: displacement and betrayal. In contrast to the process of knowledge translation described by Bennet and Jessani (2011) our research shows that in 'real-world' situations, brokers cannot simply be a conduit for information to flow. Knowledge translation is far more active and precarious. The precarious nature of the role is that our brokers had to decide what to leave in and what to take out, what to say and what not to say, what to simplify and what to expand on. In order to make these decisions, brokers need, either explicitly or implicitly, to decide what the rationale or focus for the translation and integration is. Many of our brokers explicitly used community values in the assessment framework. They integrated and translated the technical work to make clear what the consequences of future scenarios would be on those community values. If they had chosen a different focus it would have resulted in different aspects of the technical work being presented, making those decisions open to interpretation and criticism. It is these translation dimensions of brokering that make the role active and precarious.

At the operational level, the assessment framework was an amalgam of different knowledges, epistemic practices and divergent values, which required bridging brokering practices. The assessment framework was an effective boundary object that enabled the technical team to 'inhabit' the values of the ZC. However, to produce evidence in a format that was recognisable 
to the planning process (e.g., mutually exclusive and colour coded categories informed by science and scientific methods), our brokers had to build boundaries. The assessment framework allowed our brokers to bridge boundaries at the operational level and build boundaries at the knowledge system level. The semblance of detachment (and potentially honesty) that the assessment framework fostered was not achieved by disinterestedly integrating strands of disciplinary science to package up and communicate options, as advanced by popular conceptions of the knowledge translation and knowledge broker role (Bennet and Jassani, 2011; Gluckman, 2014). Rather, the 'brokered knowledge' (Meyer, 2010, p. 123) was a product of what was included and excluded from the assessment framework for justifiable reasons. It was a product of myriad negotiations embodied in the co-production and brokering of knowledges, practices and values of those sitting around the table (i.e., those directly involved in the intervention), as well as the political context of the knowledge system within which this collaborative decision-making intervention took place (van Kerkhoff and Pilbeam, 2017). It was the broker's role to weave it all together.

\section{Conclusions}

This paper has investigated the complexities of brokering through reflections from technical team leads that worked as brokers at the interface of science and policy in a conflicted situation where divergent knowledges, epistemic practices and values and uncertainties had to be integrated and translated for use in policy. When we look at what brokers do in practice in such contentious resource management contexts, we can see they cannot simply act as conduits for information to flow from scientists to policymakers or communities in a process akin to funnelling, with translation extending largely to packaging. In practice, complex technical work full of uncertainties and assumptions could not simply be passed from one actor or stage of the process to another (i.e., a baton change) without boundary work that required active and precarious translation. Brokering in the real-world is not merely a matter of serving wine that has been sitting in a cellar (Bennett and Jessani, 2011).

From the outset, the broker role was created by ECan to change the way science was used in policy and to set resource limits. While it appeared relatively straightforward to shift from a knowledge arbiter to a knowledge broker, the role involved our participants in the ongoing drawing of boundaries to distribute authority, roles and responsibilities in efforts to retain their credibility, having taken on roles so closely involved with policy (Duncan, 2013b, 2017). ZC decisions shaped and were shaped by the technical work and the boundary work of brokers who grappled with the provisions of the CWMS, the values of the people sitting around the ZC table, the wider institutional and political environment within which limitsetting was occurring and the inevitable uncertainties. In this context, brokering was very much about co-producing knowledge and policy in tandem. We found that brokers were building as much as they were bridging or blurring science policy boundaries in the integration and translation work they were doing to deliver policy-useable knowledge (Jasanoff, 2004; Leith et al., 2017). From this perspective, brokering is an embedded rather than detached role that is fundamentally active and profoundly precarious.

This research has implications for practitioners who are often working with idealised notions of the broker and a 'two communities logic'. Knowledge brokers are usually presented as a solution to a problem conceived as needing to bridge unconnected science and policy communities (Wehrens, 2014). We have argued that brokers are embedded in a set of complex and value-laden relations rather than operating as detached actors.
They build as well as bridge and blur boundaries as they work across operational and knowledge system levels of co-production. They are engaged in vertical as well as horizontal boundary work. The absorptive aspect of the role requires brokers to absorb the different tolerances of uncertainty at the operational level and reconcile these with perceived knowledge system requirements for how uncertainties are expected to be managed (e.g., preferably hidden from view). This means they had to make deeply difficult decisions at multiple levels about what is passed on and what is kept back and ultimately taking responsibility for the rationale governing the way science, policy and politics were integrated and translated. Their expertise resides in working with sensitivity, empathy, humility, reflexivity, flexibility and pragmatism to enable them to work across these multiple dimensions, and being resilient enough not to sink under the collective weight of all the uncertainties and decisions they must absorb.

Importantly, the expertise required by these brokers goes beyond these qualities. They all had a disciplinary background in the natural sciences, and they all drew on this expertise. However, the brokering role required them to be reflective and critical on behalf of the combined work of many disciplines and knowledge sources. This required transdisciplinary expertise, for which they had no formal training. They gained this expertise through experience and reflection. While each of the brokers in this study gained valuable transdisciplinary expertise, the absence of comprehensive guidance means newcomers often rely on intuition to invent ways of dealing with these challenges (Schon, 1995; Pohl and Hirsch Hadorn, 2008; Jahn et al., 2012; Bammer, 2013), which risks reinventing the wheel (Tress et al., 2007) and can take a considerable personal toll on those attempting to undertake the broker role.

Failure to acknowledge the complexities of the broker role, the diverse expertise it requires, and the context within which it is coproduced will make the job of brokering even more difficult, especially for new and inexperienced brokers as they strive to walk an idealised path through the no-man's land between misrepresentations of the science and policy realms.

Epilogue. Providing a draft of this paper to our participants elicited a further insight. The idea that brokers are involved in building boundaries between the domains of science and policy, as well as bridging them was particularly challenging for our brokers to conceive given the former is not what brokers set out to do nor what they see themselves doing. However, for at least one broker, recognising the fallacy of the 'two communities logic' and notions of a fixed and pre-existing boundary between science and policy 'has been profound'. Recognising science policy boundaries at multiple levels are not set in stone means there can be transparent discussions about what is in and out of scope and negotiations can take place about where the boundary is to be drawn. It profoundly changes what it is that brokers see themselves doing in practice.

\section{Data availability}

The data of this research consists of interview transcripts (as word documents) that have been professionally transcribed from digitally recorded interviews. Commitments were made to research participants (as required by the social ethics process) that their contributions contained in these transcripts would be confidential and accessed only by the research team. To make this data available would require obtaining permission from the research participants, which we could seek. The themes derived from the analysis of the interviews are available.

Received: 4 December 2019; Accepted: 26 March 2020; Published online: 22 April 2020 


\section{References}

Bammer G (2013) Disciplining interdisciplinarity: Integration and implementation sciences for researching complex real-world problems. ANU E Press. https:// doi.org/10.22459/DI.01.2013

Becker A (2017) Using boundary objects to stimulate transformational thinking: storm resilience for the Port of Providence, Rhode Island (USA). Sustainability Sci 12(3):477-501

Bennett G, Jessani N (eds) (2011) The knowledge translation toolkit: Bridging the know-do gap: A resource for researchers. SAGE Publications, India

Cash D W, Clark W C, Alcock F, Dickson N M, Eckley N, Guston D H, Jager J, Mitchell R B (2003) Knowledge systems for sustainable development. Proc Natl Acad Sci USA 100(1):8086-8091

Cash DW, Borck JC, Patt AG (2006) Countering the loading-dock approach to linking science and decision making: comparative analysis of El Niño/ Southern Oscillation (ENSO) forecasting systems. Sci Technol Hum Values 31(4):465-494

(2009) Canterbury Water Management Strategy. Strategic Framework November 2009. Targets updated July 2010. Canterbury Regional Council, Christchurch

Cope M (2015) Coding qualitative data in Qualitative Research Methods in Human Geography. Second Edition. Edited by Iain Hay. Oxford University Press, South Melbourne, Victoria

Duncan R (2008) Problematic practice in integrated impact assessment: the role of consultants and predictive computer models in burying uncertainty. Impact Assess Proj Appraisal 26(1):53-66

Duncan R (2013a) Opening new institutional spaces for grappling with uncertainty: a constructivist perspective. Environ Impact Assess Rev 38:151-154

Duncan R (2013b) Converting community knowledge into catchment nutrient limits: a constructivist analysis of a New Zealand collaborative approach to water management. Nat Cult 8(2):205-225

Duncan R (2016) Ways of knowing-out-of-sync or incompatible? Framing water quality and farmers' encounters with science in the regulation of non-point source pollution in the Canterbury region of New Zealand. Environ Sci Policy 55:151-157

Duncan R (2017) Rescaling knowledge and governance and enrolling the future in New Zealand: a co-production analysis of Canterbury's water management reforms to regulate diffuse pollution. Soc Nat Resour 30 (4):436-452

Evans S, Scarbrough H (2014) Supporting knowledge translation through collaborative translational research initiatives: 'Bridging'versus 'blurring'boundary-spanning approaches in the UK CLAHRC initiative. Soc Sci Med 106:119-127

Fenemor A, Phillips C, Allen W, Young RG, Harmsworth G, Bowden B, Basher L, Gillespie PA, Kilvington M, Davies-Colley R, Dymond J (2011) Integrated catchment management-interweaving social process and science knowledge. NZ J Mar Freshw Res 45(3):313-331

Fenemor A (2014) Managing technical communication and information risks during collaborative catchment limit-setting processes. Landcare Research Contract Report LC1881 prepared for Environment Canterbury

Funtowicz SO, Ravetz JR (1991) A new scientific methodology for global environmental issues. Ecol Econ: Sci Manag Sustainability 10:137-152

Gieryn T (1983) Boundary-work and the demarcation of science from non-science: strains and interests in professional ideologies of scientists. Am Sociological Rev 48:781-795

Gilbert GN, Mulkay M (1984) Opening Pandora's box: A sociological analysis of scientists' discourse. Cambridge University Press, Cambridge

Gluckman P (2014) Policy: The art of science advice to government. Nature 507 (7491):163-165

Gluckman P (2017a) How science informs current thinking in government. Address to New Zealand Institute of Agricultural and Horticultural Sciences Symposium on 'Science in a Post-Truth Era', 24 August 2017, Lincoln

Gluckman P (2017b) Enhancing evidence-informed policy making: a report by the Prime Minister's Chief Science Advisor. Office of the Prime Minister's Chief Science Advisor, Auckland, https://www.pmcsa.org.nz/wp-content/uploads/ 17-07-07-Enhancing-evidence-informed-policy-making.pdf

Gluckman P (2017c) Perspectives on science advising: what are the skills needed? Presentation to the International Network for Government Science Advice, 17 March, 2017 in Brussels. Office of the Prime Minister's Chief Science Advisor, Auckland, https://www.pmcsa.org.nz/wp-content/uploads/17-0317-Perspectives-on-science-advising.pdf

Guston DH (2001) Boundary organizations in environmental policy and science: an introduction. Sci, Technol Hum Values 26(4):399-408

Henley G (2014) Review of environmental limit setting process in four zones. Environment Canterbury, Christchurch

Hilger A, Rose M, Wanner M (2018) Changing faces- factors influencing the roles of researchers in real-world laboratories. GAIA - Ecol Perspect Sci Soc 27 (1):138-145

Hoppe R, Wesselink A, Cairns R (2013) Lost in the problem: the role of boundary organisations in the governance of climate change. WIREs Clim Change 4:283-300. 10.1002.wcc. 225
Irwin A, Wynne B (eds) (2003) Misunderstanding science? the public reconstruction of science and technology. Cambridge University Press, Cambridge, UK

Jahn T, Bergmann M, Keil F (2012) Transdisciplinarity: Between mainstreaming and marginalization. Ecol Econ 79:1-10. https://doi.org/10.1016/j. ecolecon.2012.04.017

Jasanoff S (1987) Contested boundaries in policy-relevant science. Soc Stud Sci 17:195-230

Jasanoff S (1990) The fifth branch: science advisers as policymakers. Harvard University Press, Cambridge MA

Jasanoff S (ed) (2004) States of knowledge: the co-production of science and the social order. Chapters 1, 2 and 14. Routledge, London

Latour B (2004) Politics of nature. Harvard University Press, Cambridge MA

Latour B (1993) We have never been modern. Harvard University Press, Cambridge MA

Lavis J N, Lomas J, Hamid M, Sewankambo N K (2006) Assessing country-level efforts to link research to action. Bulletin of the World Health Organization (84):620-628

Law J (1994) Organizing modernity. Blackwell, Oxford

Law J (2002) Aircraft stories: decentering the object in technoscience. Duke University Press, North Carolina

Law J (2004) After method: mess in social science research. Routledge, London and New York

LAWF (Land and Water Forum) (2012) Third report of the land and water forum: managing water quality and allocating water. http://www.landandwater.org. nz/ (accessed 1 Feb 2013)

Leith P, O’Toole K, Haward M, Coffey B, Rees C, Ogier E (2014) Analysis of operating environments: a diagnostic model for linking science, society and policy for sustainability. Environ Sci Policy 39:162-171

Leith P, Vanclay F (2015) Translating science to benefit diverse publics: engagement pathways for linking climate risk, uncertainty, and agricultural identities. Sci, Technol, Hum Values 40(6):939-964

Leith P, O'Toole K, Haward M, Coffey B (2017) Enhancing science impact: bridging research, policy and practice for sustainability. CSIRO Publishing, Clayton South, Victoria

Lövbrand E (2007) Pure science or policy involvement? Ambiguous boundarywork for Swedish carbon cycle science. Environ Sci Policy 10(1):39-47

McNie EC (2007) Reconciling the supply of scientific information with user demands an analysis of the problem and review of the literature. Environ Sci Policy 10:17-38

Machen R (2018) Towards a critical politics of translation:(Re) Producing hegemonic climate governance. Environ Plan E: Nat Space 1(4):494-515

Merriam S, Tisdell EJ (2015) Qualitative research: a guide to design and implementation, Fourth Edition. John Wiley \& Sons, San Francisco

Meyer M (2010) The rise of the knowledge broker. Sci Commun 32(1):118-127

Meyer M, Kearnes M (2013) Introduction to special section: Intermediaries between science, policy and the market. Sci Public Policy 40(4):423-429

(2017) National policy statement for freshwater management implementation review: National Themes Report. Ministry for the Environment, Wellington

New Zealand Government (2010) Environment Canterbury (Temporary Commissioners nd Improved Water Management) Act, 2010. Parliamentary Counsel Office, Wellington,

Pettit C, Ewing S, Coffey B, Geraghty P, Hocking G, Meyers N, Butters S, Weston $M$ (2011) Exploring the potential of knowledge brokering to enhance natural resource management: findings from the Catchment Knowledge Exchange project in Victoria. Australasian. J Environ Manag 18 (4):233-247

Pielke Jr RA (2007) The honest broker: making sense of science in policy and politics. Cambridge University Press, Cambridge

Pohl C, Hirsch Hadorn G (2008) Methodological challenges of transdisciplinary research. Nat Sci Sociétés 16:111-121

Pohl C, Rist S, Zimmermann A, Fry P, Gurung GS, Schneider F, Ifejika Speranza C Kiteme B, Boillat S, Serrano E, Hirsch Hadorn G, Wiesmann U (2010) Researchers' roles in knowledge co-production: experience from sustainability research in Kenya, Switzerland, Bolivia and Nepal. Sci Public Policy 37 (4):267-281

Rennie H (2010) The ECan Act: understanding the new provisions for planners. Linc Plan Rev 2(2):20-21

Robson M C (2014) Technical report to support water quality and water quantity limit setting process in Selwyn Waihora catchment. Predicting consequences of future scenarios: Overview report. Environment Canterbury Technical Report

Robson-Williams M, Norton N, Davie T, Taylor K, Kirk N (2018) The changing role of scientists in supporting collaborative land and water policy in Canterbury, New Zealand. Case studies in the environment October:1-5. https:// doi.org/10.1525/cse.2018.001271

Sarewitz D, Pielke Jr RA (2007) The neglected heart of science policy: reconciling supply of and demand for science. Environ Sci Policy 10(1):5-16

Sarkki S, Heikkinen HI, Karjalainen TP (2013) Sensitivity in transdisciplinary projects: a case of reindeer management in Finland. Land Use Policy 34:183-192 
Schon D (1983) The reflective practitioner: how professionals think in action. Temple Smith, London

Schon DA (1995) The new scholarship requires a new epistemology. Change 27 (Nov/Dec):27-34

Star SL, Griesemer J (1989) Institutional ecology, 'translations' and boundary objects: amateurs and professionals in Berkeley's museum of vertebrate zoology, 1907-39. Soc Stud Sci 19(3):387-420

Strauss A, Corbin J (2009) Basics of qualitative research in grounded theory, procedures and techniques. Sage, Newbury Park

Tress G, Tress B, Fry G (2007) Analysis of the barriers to integration in landscape research projects. Land Use Policy 24(2):374-385. https://doi.org/10.1016/j. landusepol.2006.05.001

Tuinstra W, Hordijk L, Kroeze C (2006) Moving boundaries in transboundary air pollution co-production of science and policy under the convention on long range transboundary air pollution. Glob Environ Change 16(4):349-363

Turnhout E, Stuiver M, Klostermann J, Harms B, Leeuwis C (2013) New roles of science in society: different repertoires of knowledge brokering. Sci Public Policy 40(3):354-365

van Kerkhoff L, Pilbeam V (2017) Understanding socio-cultural dimensions of environmental decision-making: A knowledge governance approach. Environ Sci Policy 73:29-37

Weber EP, Memon A, Painter B (2011) Science, society, and water resources in New Zealand: recognizing and overcoming a societal impasse. J Environ Policy Plan 13(1):49-69

Wehrens R (2014) Beyond two communities-from research utilization and knowledge translation to co-production? Public Health 128(6):545-551

Weinberg AM (1972) Science and trans-science. Minerva 10(2):209-222

(2004) World report on knowledge for better health: strengthening health systems

Wittmayer JM, Schapke N (2014) Action, research and participation: roles of researchers in sustainability transitions. Sustainability Sci 9(4):483-496

Wyborn C (2015) Connectivity conservation: boundary objects, science narratives and the co-production of science and practice. Environ Sci Policy 51:292-303

Wyborn C, Datta A, Montana J, Ryan M, Leith P, Chaffin B, Miller C, Van Kerkhoff L (2019) Co-producing sustainability: Reordering the governance of science, policy, and practice. Annu Rev Environ Resour 44:319-346

\section{Acknowledgements}

We sincerely thank our participants who were willing to give up their time to talk with us and reflect upon their experiences and the draft paper. This work was supported by Manaaki Whenua-Landcare Research internal investment (682401-0105).

\section{Competing interests}

The authors declare no competing interests.

\section{Additional information}

Correspondence and requests for materials should be addressed to M.R.-W.

Reprints and permission information is available at http://www.nature.com/reprints

Publisher's note Springer Nature remains neutral with regard to jurisdictional claims in published maps and institutional affiliations.

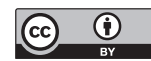

Open Access This article is licensed under a Creative Commons Attribution 4.0 International License, which permits use, sharing, adaptation, distribution and reproduction in any medium or format, as long as you give appropriate credit to the original author(s) and the source, provide a link to the Creative Commons license, and indicate if changes were made. The images or other third party material in this article are included in the article's Creative Commons license, unless indicated otherwise in a credit line to the material. If material is not included in the article's Creative Commons license and your intended use is not permitted by statutory regulation or exceeds the permitted use, you will need to obtain permission directly from the copyright holder. To view a copy of this license, visit http://creativecommons.org/ licenses/by/4.0/.

(C) The Author(s) 2020 